\title{
Rafał Kamiński
}

University of Białystok

mskaminskirafal@gmail.com

\section{Characteristics of Selected Institutions of Probation in the Context of the Participation of Non-Governmental Organizations in their Implementation}

\begin{abstract}
This article is an attempt at presenting the problem of probation in Poland. It contains a summary of the institutions falling within the definition of this concept. The article is divided into three parts. The first two concern the solutions contained in the Polish Penal Code. The third part is devoted to the subject of social factor's participation in the form of non-governmental organizations. The paper also presents statistics illustrating the scale of the phenomenon of probation in Poland.

Keywords: probation, community, restorative justice
\end{abstract}

\section{Institutions of probation - definitions}

The institution of probation developed in the Anglo-American legal system in the middle of the 19th century as a measure of response to juvenile delinquency. It involved finding a perpetrator guilty as charged, suspending a sentence, obliging a convicted offender to perform certain duties during a trial period, and determining a trial period under a supervision of a probation officer ${ }^{1}$. Probation is based on the assumption according to which punishing an offender is not always necessary to fulfil a purpose of punishment, in particular preventing him or her from returning to crime. Moreover, economical reasons additionally support the claim according to which perpetrators who committed acts that are not seriously socially detrimental should not be subject to deprivation of liberty; instead they should be subject to a measure which would be relatively repressive but, at the same time, would not force the State to pay the cost of perpetrator's incarceration ${ }^{2}$.

1 J. Warylewski, Prawo karne. Część ogólna, Warszawa 2012, p. 463.

2 S. Hypś, (in:) A. Grześkowiak, K. Wiak (ed.), Kodeks karny. Komentarz, Warszawa 2014, p. 364. 
Positive practical effects of probation at the beginning of its introduction in the middle of the 19th century ensued its implementation into the legal systems of most countries of then Europe, which resulted in the establishment of several versions of the discussed measure: a Danish-Norwegian-Dutch model, which involved suspension of all criminal proceedings, already mentioned Anglo-American model based on sentencing entailing simultaneous suspension of a sentence, a German model where a decision to suspend a sentence was not vested in the court but an executive body, and a French-Belgian model which allowed to sentence and simultaneously suspend a sentence for a trial period that finished with the sentence annulment. Solutions adopted in the Polish Criminal Code of $1932^{3}$ were based on the latter modification of the above discussed measure.

The currently binding Act of 6 June 1997 - Criminal Code ${ }^{4}$, contains three measures connected with putting a perpetrator to a test (trial): conditional discontinuation of proceedings, probation (conditionally suspended sentence) and parole (conditional release from prison after serving a part of the sentence). The first two measures may be combined with a sentence imposing on a perpetrator several duties which are determined in the Criminal Code as well. It is an original and unique approach to the issue of applying institutions of probation because one legal act regulates the issue of more than one measure connected with putting a perpetrator to a test (trial) ${ }^{5}$.

\section{Conditional discontinuation of criminal proceedings}

Probation in a form of conditional discontinuation of proceedings is an institution from the borderline of substantive criminal law and procedural criminal law; i.e. petty offences with a concurrent positive profile of a perpetrator should not ensue his or her sentence but should fulfil as many purposes of criminal proceedings as possible by the application of appropriate burdens. Most generally speaking, conditional discontinuation of proceedings is a measure of probation based on abandonment of sentencing and punishing a perpetrator guilty of the offence ${ }^{6}$.

As pointed out by the Supreme Court, conditional discontinuation of proceedings should be "a measure deepening individualization of criminal liability and a measure of rehabilitation considerably limiting the application of short-term deprivations of liberty or penalties not connected with deprivation of liberty, and replacing such penalties with educational or correctional measures assuring perpetrator's

\footnotetext{
J. Warylewski, Prawo karne..., op. cit., p. 463-464.

Uniform text: Journal of Laws of 2016, item 1137.

S. Hypś, (in:) A. Grześkowiak, K. Wiak (ed.), Kodeks karny..., op. cit., p. 364, G. Łabuda, (in:) J. Giezek (ed.), Kodeks karny. Część ogólna. Komentarz, Warszawa 2012, p. 470.

T. Bojarski, (in:) T. Bojarski (ed.), Kodeks karny. Komentarz, Warszawa 2013, p. 197; P. Kozłowska-Kalisz, (in:) M. Mozgawa (ed.), Kodeks karny. Komentarz, Warszawa 2015, p. 215-217; J. Warylewski, Prawo karne..., op. cit., p. 465.
}

6 
improvement if they are petty offenders with a clean criminal record, and positively affecting the perception of law without the need to sentence the offender"7.

The institution of conditional discontinuation of proceedings was introduced to the Polish legal system together with the implementation of Criminal Code of 1969, which was connected with the then existing phenomenon called a crisis of deprivation of liberty. It somehow forced legislators in many countries to search alternatives to the above mentioned penalty, especially if it was short-term ${ }^{8}$.

The reasoning to the governmental draft of Criminal Code of 1969 emphasized that conditional discontinuation of proceedings was, in fact, controlled freedom which, in case of a negative outcome, allowed to impose a rational penalty or penal measure. What is more, it was depicted that the application of conditional discontinuation of proceedings eliminates a need to hold a hearing, which considerably accelerates litigation thus satisfying the principle of procedural economics. Additionally, a decision on the application of the discussed penal measures protects an offender against stigmatization connected with serving time in prison ${ }^{9}$.

\section{Legal nature of conditional discontinuation of criminal proceedings}

From the very beginning, conditional discontinuation of proceedings arouse doubts as to its legal nature. Unfortunately, the volume of the study does not permit an accurate analysis of the described issue. Nevertheless, it is necessary to briefly present the problem due to its significance.

A basic division in the doctrine was generated by the question whether the discussed measure is a sentence but without punishment, or whether conditional discontinuation of proceedings is not a form of criminal liability, i.e. it is not a sentence ${ }^{10}$. Although the first opinion enjoyed considerable support, now the second one prevails among the doctrine representatives. They underline that even though conditional sentencing itself acknowledges that the defendant committed an act he or she has been charged with, it is merely a new form of legal, not criminal, liability ${ }^{11}$. Furthermore, the second opinion was strongly supported by the judicature, which also believed that conditional discontinuation of proceedings could not be treated as a specific kind of a sentence. For instance, the Supreme Court ruled that "a verdict which conditionally discontinued criminal proceedings does not have a character of a sentence, therefore requirements contained in the provision of Art. $413 \S 2$ of the

\footnotetext{
7 Resolution of Supreme Court's Criminal Chamber of 29 January 1971, VI KZP 26/69, OSNKW 1971, No. 3, item 33.

8 B. Kunicka-Michalska, Warunkowe umorzenie postępowania karnego, (in:) M. Melezini (ed.), System Prawa Karnego. Kary i środki karne. Poddanie sprawcy próbie. Volume 6, Warszawa 2010, p. 938.

9 S. Hypś, (in:) A. Grześkowiak, K. Wiak (ed.), Kodeks karny..., op. cit., p. 364-365.

10 B. Kunicka-Michalska, Warunkowe..., op. cit., p. 953.

11 Ibidem, p. 953-954.
} 
Code of Criminal Procedure do not apply thereto" ${ }^{12}$. The Constitutional Tribunal held a similar opinion claiming that "a difference in determining necessary component elements of a sentence and ruling of conditional discontinuation is not accidental; it expresses the legislator's will as to the legal structure of conditional discontinuation of proceedings"13. Moreover, the doctrine is engaged in a dispute whether the discussed institution should be treated as: a release from criminal liability, a measure of criminal law response to a crime, a form of conditional sentencing, a penal measure connected with putting an offender to a trial or test, or a manifestation of opportunism in crime prosecution ${ }^{14}$. It is also important that the application of the discussed measure of probation is a manifestation of infringed presumption of innocence because conditional discontinuation of proceedings and imposition on the convicted offender obligations described further in the study occur despite the fact that his or her guilt has not been proved by a legally binding sentence ${ }^{15}$.

\section{Prerequisites to apply conditional discontinuation of criminal proceedings}

Pursuant to the currently binding Criminal Code of 1997, the legislator conditioned the application of conditional discontinuation of proceedings on the parallel occurrence of all prerequisites specified in Art. $66 \$ 1-3$ of the Criminal Code, i.e.: insignificant guilt and social harm of the act, no doubts as to the commission of the act, a clean criminal record of a perpetrator with regard to intentional offences, a positive criminological forecast and a condition that an offence committed by a perpetrator is punished by a maximum 5 years imprisonment. The prerequisite of insignificant guilt, whose occurrence is required for the application of the discussed measure, arises considerable problems in practice because it requires reference to the catalogue of circumstances mitigating guilt; yet, at the same time, it does not permit the application of circumstances excluding it. Each time, it forces courts to assess a factual state of the case pursuant to their knowledge, experience and principles of criminal procedure ${ }^{16}$. The prerequisite of insignificant social harm of the act causes much fewer problems because the court may herein refer to the content of Art. $115 \$ 2$ of the Criminal Code, which lists prerequisites that establish criteria which are taken into account to determine a degree of social harm of an att $^{17}$. We should also remember that conditional discontinuation of proceedings is possible only when both above

Supreme Court's judgment of 3 October 2008, III KK 167/08 (not published)

Constitutional Tribunal's judgment of 16 May 2000, P 1/99, OTK 2000, No. 4, item 111.

R.A. Stefański, Prawo karne materialne. Część ogólna, Warszawa 2008, p. 348.

More on presumed innocence in, i.a.: A. Jezusek, "Domniemanie winy" w prawie karnym materialnym a procesowe domniemanie niewinności, "Ruch Prawniczy, Ekonomiczny i Socjologiczny" 2016, No. 2, p. 175-187.

G. Łabuda, (in:) J. Giezek (red.), Kodeks karny..., op. cit., p. 471.

B. Kunicka-Michalska, Warunkowe..., op. cit., p. 988. 
mentioned prerequisites occur. Nevertheless, each of them must be established separately and independently ${ }^{18}$.

No doubts as to the fact that the offender committed the act he or she is charged with is not only the prerequisite necessary to apply the institution of conditional discontinuation of proceedings; it also fulfils the function of a guarantee because it protects him or her against the application of the discussed measure if the defendant should be acquitted ${ }^{19}$. As pointed out by the Supreme Court, a decision on conditional discontinuation of proceedings taken by a court will be right only if a factual state of the case does not arise any doubts in the light of collected evidence and assessment made by the court. Just on the basis of this evidence does the court determine the defendant's perpetration, a degree of his or her guilt and social harm of the act, i.e. circumstances which imply another prerequisite of conditional discontinuation of proceedings, that is the prerequisite of no doubts as to the commission of the $\mathrm{act}^{20}$. What is more, both the doctrine and judicature believe that if the defendant pleads guilty, it does not imply that the discussed prerequisite has been satisfied, whereas if he or she does not plead guilty, the adjudicating body is merely forced to be more careful as to the application of the discussed measure ${ }^{21}$. Previous clean criminal record as the prerequisite of applying the institution of conditional discontinuation of proceedings embraces all binding sentences which have been passed before the application of the discussed institution is adjudicated. The subject requirement is applied not only when an offender is convicted of a crime or intentional misdemeanour, but also when punishment is renounced, or when measures envisaged for minors or security measures are applied ${ }^{22}$. Yet the doctrine and judicature simultaneously claim that the requirement of clean criminal record refers not only to intentional offences but also intentional-unintentional, and concerns sentencing a perpetrator to one of the penalties envisaged in Art. 32 of the Criminal Code ${ }^{23}$. The Supreme Court also emphasizes that "a condition of previous clean criminal record for intentional offences is of an absolute nature and does not depend on the knowledge of the court hearing the case"24. At the same time, we should remember that a previous conviction for intentional offence does not matter when a decision on the application of conditional discontinuation of proceedings is taken if it has already been erased ${ }^{25}$.

\footnotetext{
18 P. Hofmański, L.K. Paprzycki, (in:) M. Filar (ed.), Kodeks karny. Komentarz, Warszawa 2012, p. 354.

19 S. Hypś, (in:) A. Grześkowiak, K. Wiak (ed.), Kodeks karny..., op. cit., p. 367.

20 Supreme Court's judgment of 20 October 2011, III KK 159/11, Lex No. 1101665.

21 P. Hofmański, L.K. Paprzycki, (in:) M. Filar (ed.), Kodeks..., op. cit., p. 354; G. Łabuda, (in:) J. Giezek (ed.), Kodeks karny..., op. cit., p. 475; Supreme Court's judgment of 11 July 1985, RNw 17/85, OSNKW 1986, No. 3/4, item 18.

22 P. Kozłowska-Kalisz, (in:) M. Mozgawa (ed.), Kodeks karny..., op. cit., p. 215-217.

23 S. Hypś, (in:) A. Grześkowiak, K. Wiak (ed.), Kodeks karny..., op. cit., p. 368; G. Łabuda, (in:) J. Giezek (ed.), Kodeks karny..., op. cit., p. 474; Supreme Court's decision of 1 October 2003, II KK 156/03, OSNwSK 2003 , No. 1 , item 2080 .

24 Supreme Court's judgment of 1 February 2011, IV KK 406/10, Lex No. 725081.

25 P. Hofmański, L.K. Paprzycki, (in:) M. Filar (ed.), Kodeks..., op. cit., p. 355.
} 
The prerequisite of positive criminological forecast is the most subjective among all requirements necessary to apply the discussed measure even though deciding about conditional discontinuation of proceedings, the court must have justified reasons to assume that the convicted offender will follow legal order and will not reoffend in particular ${ }^{26}$. Deciding about the application of the discussed institution, the court pays attention to the perpetrator's conduct and attitude (especially whether he or she shows repentance, expresses willingness to improve, or whether the event was incidental), his or her personal features and conditions (understood as personal qualities and temper but also a level of education), and a previous lifestyle (especially those elements of the perpetrator's life which contributed to a crime committed by him or her such as their environmental, family and housing conditions $)^{27}$.

A limit of maximum penalty necessary to apply the institution of conditional discontinuation of proceedings cannot exceed five years. This is the only prerequisite of a stricte formal nature. This entails that the application of possible extraordinary mitigation or aggravation of penalty envisaged by the law does not affect its occurrence $^{28}$.

\section{Final comments on conditional discontinuation of criminal proceedings}

The discussed measure of probation is of a solely elective nature and may be adjudicated exclusively by a court ruling. Confirming the occurrence of the above mentioned prerequisites, instead of the indictment the prosecutor may apply to the court for the application of the discussed institution towards a perpetrator proposing a trial period and duties the defendant should fulfil and, possibly, determine the scope of probation $^{29}$.

Conditional discontinuation of proceedings is adjudicated for a trial period from one to three years counting from the day on which a decision on this measure's application has become final and binding. Its aim is to verify a criminological forecast and exert educational or correctional impact on a perpetrator ${ }^{30}$.

Furthermore, the court may put a perpetrator on probation under a supervision of a probation officer or a trustworthy person, association, institution or social or-

\footnotetext{
26 B. Kunicka-Michalska, Warunkowe..., op. cit., p. 996.

27 S. Hypś, (in:) A. Grześkowiak, K. Wiak (ed.), Kodeks karny..., op. cit., p. 369; G. Łabuda, (in:) J. Giezek (ed.), Kodeks karny..., op. cit., p. 475.

P. Kozłowska-Kalisz, (in:) M. Mozgawa (ed.), Kodeks karny..., op. cit., p. 215-217.

R.A. Stefański, Prawo..., op. cit., p. 352.

J. Warylewski, Prawo..., op. cit., p. 466; P. Kozłowska-Kalisz, (in:) M. Mozgawa (ed.), Kodeks karny..., op. cit., p. 218-219.
} 
ganization whose activities involve educational care, prevention of demoralization or help and assistance provided to convicted offenders ${ }^{31}$.

Deciding to conditionally discontinue proceedings, the court obliges a perpetrator to redress harm fully or partly and, as far as possible, imposes on him or her a duty to compensate the afflicted harm, or otherwise the court adjudicates exemplary damages instead of these obligations. Additionally, depending of the needs, the court obliges a perpetrator to inform the court or probation officer about the course of a trial period, apologize to the victim, exercise the obligation to maintain another person he or she is burdened with, refrain from abusing alcohol or other intoxicating substances, undertake addiction therapy, undertake therapy, in particular psychotherapy or psycho-education, participate in correctional-educational activities, refrain from contacting the victims or other persons in a specified manner or approaching the victim or other persons, and move out a place or residence occupied together with the victim. Moreover, the court may apply penal measures in a form of pecuniary consideration or a ban on driving a vehicle for two years ${ }^{32}$.

In 2015, 26959 proceedings were conditionally discontinued before first-instance courts, including 26153 initiated by the prosecutor and 747 - by a private individual. It is a decline in comparison to 2014, when 27418 proceedings were conditionally discontinued, 26725 initiated by the prosecutor and 663 - by a private individual, respectively ${ }^{33}$.

The court is obliged to launch conditionally discontinued proceedings if the perpetrator committed an intentional offence he or she has been convicted of during a trial period. The proceedings are optionally launched if the perpetrator grossly violates legal order, avoids obligations he or she has been imposed on and, in particular, if he or she has committed another offence ${ }^{34}$. In the discussed cases, however, the court is obliged to launch conditionally discontinued proceedings if the convicted offender received a written admonition from a probation officer unless special considerations suggest otherwise.

\section{The institution of probation (a conditionally suspended sentence)}

Probation (a conditionally suspended sentence) is another measure contained in the Criminal Code of 1997. It is of a form of punishment where a perpetrator is sentenced to appropriate penalty but the execution thereof is concurrently renounced ${ }^{35}$. of Justice of 26 February 2013 on the Manner of the Fulfilment of Obligations and Rights by Probation Officers in Executive Criminal Cases (Journal of Laws, item 335); Regulation of Prime Minister of 1 December 2003 on Special Scope and Course of Participation of Entities in the Enforcement of Penalties, Penal, Protective and Preventive Measures and Social Control over their Execution (Journal of Laws No. 211, item 2051). 
The doctrine has emphasized from the beginning of existence of the described institution that it fulfils an important criminological-political role. Similar to conditional discontinuation of proceedings, probation (a conditionally suspended sentence) is an alternative to deprivation of liberty, which concurrently satisfies its implied individual-preventive purposes and allows the convicted offender to avoid stigmatization connected with serving time in prison thus eliminating ensuing costs thereof. What is more, the aim of probation (a conditionally suspended sentence) is to prevent perpetrator's return to crime and further violation of legal order by him or her ${ }^{36}$.

\section{Prerequisites to apply probation (a conditionally suspended sentence)}

Probation (a conditionally suspended sentence) may be applied with regard to deprivation of liberty not longer than one year. In special cases specified by the Criminal Code, it may also be adjudicated with regard to deprivation of liberty for up to five years ${ }^{37}$.

It particularly refers to situations when penalty can be extraordinarily mitigated, that is when a perpetrator "sold out" accomplices or revealed important circumstances of the offence, or upon the prosecutor's request when, regardless of evidence given by a perpetrator in his or her case, he or she revealed and presented to enforcement agencies important circumstances they had not known before referring to offences punished by deprivation of liberty for more than five years ${ }^{38}$.

Yet, we should also consider the Supreme Court's opinion, which implies that the requirement of not exceeding the length of deprivation of liberty "also refers to situations when probation regards cumulative penalty which was adjudicated in result of accumulation of deprivations of liberty and their conditional suspension"39.

Deciding about the application of the institution of probation (a conditionally suspended sentence), the court takes into account a similar scope of the substantive prerequisite which occurred with regard to conditional discontinuation of proceedings, that is the perpetrator's conduct and attitude, his or her personal features and conditions, a previous lifestyle as well as his or her conduct after committing the offence $^{40}$.

J. Skupiński, Warunkowe umorzenie postępowania karnego, (in:) M. Melezini (ed.), System Prawa Karnego. Kary i środki karne. Poddanie sprawcy próbie. Volume 6, Warszawa 2010, p. 1061; G. Łabuda, (in:) J. Giezek (ed.), Kodeks karny..., op. cit., p. 491.

37 R.A. Stefański, Prawo..., op. cit., p. 353-354; P. Hofmański, L.K. Paprzycki, (in:) M. Filar (ed.), Kodeks..., op. cit , p. 372.

38 J. Skupiński (in:), R.A. Stefański (ed.), Kodeks karny. Komentarz, Warszawa 2015, p. 468-479.

39 Supreme Court's judgment of 4 October 2004, IV KK 232/04, OSN Prok. i Pr. 2005, No. 4, item 1.

40 M. Budyn-Kulik, (in:) M. Mozgawa (ed.), Kodeks karny. Komentarz, Warszawa 2015, p. 222-225. 
As noticed by the Supreme Court, the above mentioned circumstances taken into account in adjudicating on the application of the benefit of a conditionally suspended sentence do not have a character of a closed catalogue, which is confirmed by the expression "most of all" used therein" ${ }^{41}$.

Interestingly enough, opposite to the institution of conditional discontinuation of proceedings, a previous clean criminal record of the perpetrator does not decide about the exclusion of the application of the institution of probation (a conditionally suspended sentence) in his or her case $e^{42}$. However, the Criminal Code envisages the exclusion of the discussed institution in relation to perpetrators who committed acts of hooliganism and those who were previously convicted of driving a vehicle under the influence alcohol or drugs unless special circumstances occur ${ }^{43}$.

\section{Final comments on probation (a conditionally suspended sentence)}

Similar to conditional discontinuation of proceedings, the application of the discussed measure of probation is also of an elective (optional) nature and depends only on the court's discretion as to the satisfaction of all above described prerequisites by the perpetrator ${ }^{44}$.

A sentence is conditionally suspended for a trial period from one to three years. However, it is subject to prolongation depending on the perpetrator's characteristics, i.e.: from two to five years with regard to a juvenile offender and a perpetrator who committed an offence with the use of violence harming a person residing together with him or her, and up to ten years pursuant to Art. $60 \$ 5$ of the Criminal Code ${ }^{45}$.

Adjudicating about a conditionally suspended sentence, the court may put the offender on probation under the supervision of a probation officer, a trustworthy person or appropriate social organization during a trial period. Nevertheless, the court is obliged to apply probation with regard to a juvenile offender who committed an intentional offence, a perpetrator specified in Art. $64 \$ 2$, a perpetrator who committed an offence connected with sexual deviation, and a perpetrator who committed an offence with the use of violence harming a person residing together with him or her ${ }^{46}$.

Probation (a conditionally suspended sentence) may be accompanied by a fine, which is accessory in nature and pays a role of economic hardship (discomfort) whilst, as noticed by the Supreme Court, "counteracts a wrong belief that conditionally suspended deprivation of liberty is a manifestation of leniency towards offenders" 47 .

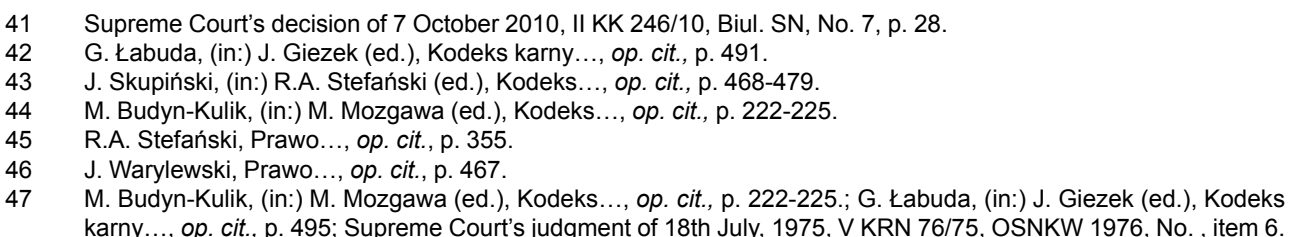


Moreover, a conditionally suspended sentence may be connected with several optional duties imposed on the perpetrator. These are: the obligation to inform the court or probation officer about the course of a trial period, apologize to the victim, exercise the obligation to maintain another person he or she is burdened with, perform paid work, study or undertake vocational training, refrain from abusing alcohol or other intoxicating substances, undertake addiction therapy, undertake therapy, in particular psychotherapy or psycho-education, participate in correctional-educational activities, refrain from visiting specified environments or places, refrain from contacting the victims or other persons in a specified manner or approaching the victim or other persons, and move out a place or residence occupied together with the victim, or behave in another appropriate manner during a trial period which may prevent reoffending ${ }^{48}$.

In 2013 courts conditionally suspended 197998 sentences, including 195345 deprivations of liberty, 1093 restrictions of liberty, and 1557 unconditioned fines, that is much more than in 2014, when courts conditionally suspended 165429 sentences, including 163534 deprivations of liberty, 897 restrictions of liberty, and 998 unconditioned fines ${ }^{49}$.

\section{Enforcement of probation by non-governmental organizations}

Probation enforced by NGOs (non-governmental organizations) is an interesting issue that is very rarely depicted in the subject literature and which is closely connected with both probation measures described above. Insofar as the institution of a probation officer is frequently discussed by both doctrine and practice, enforcement of probation by other authorized entities is marginalized.

As already mentioned above, under Art. $67 \S 2$ of the Criminal Code and Art. 73 of the Criminal Court, the court may or must put on probation a person against whom one of the above mentioned probation measures was applied under the supervision of an association, institution or social organization whose activities involve educational care, prevention of demoralization or help and assistance provided to convicted offenders.

None legal act functioning within the territory of the Republic of Poland contains a legal definition of the above mentioned organizations. Doctrine and case law are not of much help here too due to the already mentioned fact of disregarding these issues in their considerations. Thus we should approve of the approach adopted by the District Court of Krakow Sródmieście in Krakow, which ruled that the content of articles of associations of a given association, institution or social organizations, their objectives of operation contained therein in particular, should decide about classi- 
fication of an NGO as an authorized organization satisfying the provision of both Criminal Code's Articles ${ }^{50}$.

Detailed solutions concerning enforcement of probation by non-governmental organizations are envisaged by the Regulation of Prime Minister of 1 December 2003 on Special Scope and Course of Participation of Entities in the Enforcement of Penalties, Penal, Protective and Preventive Measures and Social Control over their Execution ${ }^{51}$.

The content of this legal act contains, among others, a catalogue of activities which may be performed by non-governmental organizations, determines conditions necessary to exert supervision and regulates issues of concluding relevant agreements between non-governmental organizations and entities responsible for the administration of justice within the territory of the Republic of Poland.

Interestingly enough, non-governmental organizations, which are anyway equipped with numerous rights, additionally acquired the rights to: visit persons involved in the proceedings in a place of their residence or stay including prisons and contact their families; demand necessary information and explanations from persons put on a trial period, probation or those who were imposed with obligations; cooperate with appropriate associations, organizations and institutions within the scope of improvement of housing and health conditions, employment and training of persons involved in the executive proceedings; cooperate with prison administration within the scope of appropriate preparation of inmates for release; review court files and make copies thereof in connection with the performance of activities ordered by the court; carry out environmental interviews and collect necessary information from the bodies of governmental administration, local government, workplaces, associations, organizations and institutions; undertake other activities necessary to appropriate enforcement of penalties, penal and protective measures, and provide offenders with other suitable help and assistance ${ }^{52}$.

Engagement of non-governmental organizations in the enforcement of probation of persons sentenced to parole or probation (a conditionally suspended sentence) is an attempt at encouraging citizens and local communities to voluntarily cooperate in the processes of social re-adaption of offenders, in particular helping

50 Information about the rights enjoyed by associations, organizations and institutions whose activities involve educational care, prevention of demoralization or help and assistance to convicted offenders, or trustworthy persons to enforce probation of convicted offenders or criminals is available at http://www.krakow-sr.sr.gov.pl/?c=mdPliki-cm-Pobierz-163-SW5mb3JtYWNqYSAtIDAyMjYyMTMucGRm (16.06.2014).

51 Journal of Laws No. 211, item 2051.

52 More information about may be obtained from the presentation titled Participation of society in the enforcement of judicial rulings, available at the official website of Ministry of Justice: http://bip.ms.gov.pl/ministerstwo/struktura-organizacyjna/rada-glowna-do-spraw-spolecznej-readaptacji-i-pomocy-skazanym/materialy-informacyjne-i-szkoleniowe/ (16.06.2014) and on the website devoted to NGOs at http://wiadomosci.ngo.pl/wiadomosci/830474.html (16.06.2014). 
them adapt to live in the society and, at the same time, raising legal awareness and enhancing peace and order $^{53}$.

\section{Conclusion}

Comparing and analyzing both above described institutions, it is impossible not to see the legitimacy of their application. Both conditional discontinuation of proceedings and conditional suspension of deprivation of liberty provide perpetrators who committed socially insignificant misdeeds with a possibility of bearing responsibility and satisfying other purposes envisaged for punishment while simultaneously avoiding stigmatization connected with serving time in prison and paying costs thereof by the State Treasury.

The fact that the application of the above mentioned institutions does not ensue negative effects that usually accompany deprivation of liberty speaks in their favour. Convicted offenders do not break ties with society, they do not encounter personality changes resulting from isolation from their family or environment. At the same time, convicted offenders are not subject to integration with other offenders sentenced to deprivation of liberty. Furthermore, the control they are subject to during a trial period as well as obligations they are imposed on satisfy a rightful purpose of punishment. Convicted offenders' personal features, their attitude and conduct as well as positive criminological forecast, which are prerequisites to apply the above described probation measures, make us presume that their individual-preventive nature will allow the offender be punished rationally and economically thus satisfying punishment's social and educational role (taking into account all norms of widely understood humanitarianism) and preventing re-offence.

Hence it is not surprising that both above discussed measures of probation have played an important criminal and political role since they were implemented into the Polish legal system. It may be assumed that in result of the current tendency to increase non-custodial sentences both these institutions will be more and more often applied by the courts.

\section{BIBLIOGRAPHY}

Bojarski T. (ed.), Kodeks karny. Komentarz, Warszawa 2013.

Filar M. (ed.), Kodeks karny. Komentarz, Warszawa 2012.

Giezek J. (ed.), Kodeks karny. Część ogólna. Komentarz, Warszawa 2012.

Grześkowiak A., Wiak K. (eds.), Kodeks karny. Komentarz, Warszawa 2014.

53 M. Liwski, J. Wisłowska, J. Siczek, T. Gatlik, M. Cabalski, Standardy działań probacyjnych organizacji pozarządowych, "Probacja" 2013, No. 4, http://ms.gov.pl/pl/probacja/2013 (16.06.2014). 
Jezusek A., "Domniemanie winy” w prawie karnym materialnym a procesowe domniemanie niewinności, "Ruch Prawniczy, Ekonomiczny i Socjologiczny" 2016, No. 2.

Liwski M., Wisłowska J., Siczek J., Gatlik T., Cabalski M., Standardy działań probacyjnych organizacji pozarządowych, "Probacja" 2013, No. 4.

Mały rocznik statystyczny 2015, Warszawa 2015.

Mały rocznik statystyczny 2016, Warszawa 2016.

Melezini M. (ed.), System Prawa Karnego. Kary i środki karne. Poddanie sprawcy próbie, tom 6, Warszawa 2010.

Mozgawa M. (ed.), Kodeks karny. Komentarz, Warszawa 2015. Stefański R.A. (ed.), Kodeks karny. Komentarz, Warszawa 2015. Stefański R.A., Prawo karne materialne. Część ogólna, Warszawa 2008.

Warylewski J., Prawo karne. Część ogólna, Warszawa 2012. 